Sains Malaysiana 49(12)(2020): 2989-2996

http://dx.doi.org/10.17576/jsm-2020-4912-10

\title{
A Brief Review on Smart Grid Residential Network Schemes
}

(Ulasan Ringkas Skema Rangkaian Kediaman Grid Pintar)

\author{
Noshin FAtima*, TAHSEen Amin QASURIA \& MoHD. AdiB IBRAHIM
}

\begin{abstract}
Presently the domestic zone is a fundamental part of the overall energy consumption curve. Traditional energy control grids are facing dreadful complications while handling domestic users due to the rapid growth in energy demand. However, traditional grids are mainly dependent on coal, petrol, and other expensive resources, although these resources are limited and also causing air pollution. Hence, to avoid them, alternative resources should be considered for energy production. Literature showed that renewable resources like wind, water, thermal, and solar are some of the replacements for green energy production. Their foremost advantage is that they are natural and free which will aid in the production of economic and environmental-friendly energy on a large scale. However, the residential-side consumers should also utilize the electricity responsibly via the reduction in peak hour loads, by shifting loads to off-peak hours. This will be possible through using different optimal consumption schemes for demand-side management. In this article, home energy management system schemes are discussed to reduce electricity bills for domestic consumers by modifying the peak to average ratio. The suggested schemes can be used in the future, where automatic machines will be able to communicate and make intelligent decisions with the grid. The comparative study presents a summary concerning their methods, load and cost minimization, scheduling, pricing, and coverage range. As a result, customers can select the scheme according to their requirements or can combine two or more to achieve a different kind of benefits to utilizing energy both qualitatively and quantitatively.
\end{abstract}

Keywords: Demand-side management; energy efficiency; renewable resources; smart appliances; smart grid

ABSTRAK

Pada masa ini zon domestik memainkan peranan penting dalam keluk penggunaan tenaga secara keseluruhan. Grid kawalan tenaga tradisi menghadapi komplikasi mengerikan semasa menangani pengguna domestik kerana pertumbuhan permintaan tenaga yang pesat. Walau bagaimanapun, grid tradisi tersebut bergantung kepada arang batu, petrol dan sumber lain yang mahal. Namun, sumber-sumber ini terhad dan juga menyebabkan pencemaran udara. Oleh itu, untuk mengatasi masalah tersebut, sumber alternatif harus dipertimbangkan untuk pengeluaran tenaga. Kajian kepustakaan menunjukkan bahawa sumber tenaga yang boleh diperbaharui seperti angin, air, haba dan solar adalah antara kaedah alternatif untuk penghasilan tenaga. Kelebihan utama sumber tersebut adalah daripada sumber semula jadi dan percuma yang akan membantu penjanaan tenaga yang mesra ekonomi dan mesra alam secara besar-besaran. Namun begitu, dari segi penempatan, pengguna juga harus menggunakan elektrik dengan penuh tanggung jawab melalui pengurangan beban pada waktu puncak, dengan mengalihkan beban ke luar lingkungan waktu puncak yang dapat dilakukan dengan mengamalkan skema penggunaan tenaga optimum yang berbeza. Dalam kertas ini, skema sistem pengurusan tenaga rumah dibincangkan untuk mengurangkan bil elektrik bagi pengguna domestik dengan mengubah nisbah puncak ke purata. Skema yang disarankan dapat digunakan pada masa hadapan dengan mesin akan berkomunikasi secara automatik dan membuat keputusan yang bijak pada grid. Kajian perbandingan menunjukkan ringkasan mengenai kaedah, pengurangan beban dan kos, penjadualan, penetapan harga serta liputan jaringan mereka. Oleh itu, pelanggan boleh memilih skema mengikut keperluan masing-masing atau dapat menggabungkan dua atau lebih skema untuk mencapai pelbagai jenis faedah menggunakan tenaga dengan baik secara kualitatif dan kuantitatif.

Kata kunci: Grid pintar; kecekapan tenaga; pengurusan daripada sisi permintaan; peranti pintar; sumber yang boleh diperbaharui 


\section{INTRODUCTION}

In old-style centralized systems, the grid generators were based on the small number of high voltage (HV) networks which are now replaced by some microgrids (Hannan et al. 2020). These microgrids are distributed and more reliable as compared to a centralized one. New generation power grid (microgrids) is using plants based on low voltage (LV) (Zhao et al. 2016), renewable energy sources (RES) that are water, wind, thermal (Fatima et al. 2020), and solar (Karimov et al. 2020; Wilkes \& Moccia 2011). According to a survey, the RES's provided $19 \%$ of worldwide energy utilization, which is showing a very good initial impact (Ridzuan et al. 2020). Hence, the implementation of these micro rides takes place by providing proper home energy management (HEM) system to reduce electricity bills for domestic consumers by modifying the peak to average ratio (PAR).

Although there are lots of challenging issues that have been faced like new implantation of instruments which will work on real-time supply and demand bases, which needed onetime expense is the solitary hurdle in executing smart grids. However, by looking at the increase in the previous demand for electricity, it is estimated that about $40 \%$ more energy will be needed in a residential area (Barbato \& Capone 2014). The demand and response information will be transmitted by using information technology (IT) in smart grids. Hence, the users will not only know the billing scheme but also real-time pricing, and electric device consumption (Costanzo et al. 2012). On the other side, customers can also sell their generated/ stored energy by demand management mechanisms. These mechanisms are of two types first is demand response (DR) which is from generators where other is demand-side management (DSM) done by consumers to utilize electricity efficiently (Caron \& Kesidis 2010).

The DSM technique which was first proposed in the 1970s described briefly in the next sections (Costanzo et al. 2012), some of which are optimization, and gaming theory. In optimization, the augmented solution is provided for a solo user or by combining a group of consumers (by cooperating management). The basic aim of DSM is to minimize bills (Ruiz et al. 2009), as prices are given depending upon the load at that time. When the traffic is more, then the price will be high, so in this way, one user can affect the other which might be unfair to the consumers. To avoid it, the utmost remedy in DSM is the gaming theory, it is a bit complex, as it has to handle the individual appliance of each user designed in the DSM system but a good choice. After implementations of these systems, there will be a need to design models for reference of smart grids which will be based on several blocks defined in Wu et al. (2010) as customer service provides distributors, bulk generators, operators, transmitters, and market discussed in details in upcoming sections. However, a scheme is then proposed, comprised of three main components i.e. energy management unit (EMU) using Zigbee protocol (Akestoridis et al. 2020), which is an application of wireless sensor home area network (WSHAM) for communication among devices by either star mesh or hybrid topologies, to utilize energy both qualitatively and quantitatively.

\section{MATERIALS AND METHODS}

DOMAINS OF SMART GRID

On the road to developing a domain in the smart grid, an aggregator can be introduced as an independent system operator (ISO). This ISO will act as a middle man between the grid and users. Through it, a user can not only utilize but also sell its stored energy to get some incentives. As a result, the electricity curve will be stabilized near PAR. To accomplish this, there is a need to introduce some channels by which all devices can communicate, it can be wired or wireless or a combination of both. Literature of Costanzo et al. (2011) peak-load shaving in smart homes via online scheduling showed that in case of wired the Ethernet is the best data provider up to Gbps in HAN's but it is expensive, therefore, the cheaper alternative is wireless technology some of which are Zigbee, and Wi-Fi (Xia et al. 2020). However, the drawback of wireless is its low data rate, interferences, and attenuation. Though, for long term evolution (LTE) (Alsharif et al. 2016) and by Wi-Max for 4G (Hajjawi \& Ismail 2015) are also providing wireless responsibilities with cheaper, reliable, self-healing, and elastic advantages.

\section{DSM OPTIMIZATION TECHNIQUES AND APPROACHES}

DSM algorithm classification is done in such a way, that first user interaction is defined by either individual or cooperative way. However, results showed that in cooperative, the overall price allotment is easy and all users have to pay an equal rate. But it results in injustice with some users who utilizes less energy, as the rates increase when electricity is overconsumption after a fixed threshold (Ibrahim et al. 2020). Hence, to avoid this, individual managing is much better, there can define an optimization approach that can be deterministic (when data is uncertain) or stochastic when the distribution is known (Ramos et al. 2019). 

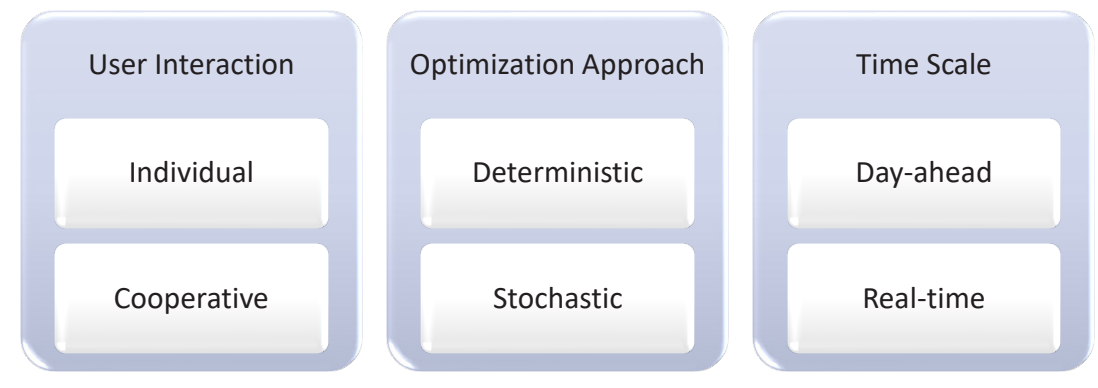

FIGURE 1. Dichotomies for the classification of DSM based on optimization methods (Barbato \& Capone 2014)

After that, the user can select either to utilize the electricity by selecting a time scale that can be obtained either on the day ahead pricing DAP or real-time pricing RTP. DAP makes a schedule based on the whole day when prices are known where RTP works on real-time data as shown Figure 1 (Barbato \& Capone 2014). The load control scheduling can minimization energy consumption by up to $66.66 \%$ of the local PAR.

\section{VARIOUS TECHNIQUES TO SCHEDULE RESIDENTIAL DSM}

This step is taken to utilize the electricity efficiently in PAR. Headed for making it possible, the consumer has to shift heavy load i.e., heaters, air conditions, to off-peak hours. To achieve it, smart appliances should be installed for automatic turning off and on according to peak and off-peak hours. To overcome the consumer demands commonly the companies which are producing electricity in peak hours turn on special peaker plants. These plants are producing expensive electricity as they are operating and utilizing electricity in peak hours too. Hence, by using small appliances users will remain connected with the report of every hour's price. It will aid in the reduction of bills, by shifting loads to off-peak hours which is one of the main goals of smart appliances. Some smart schemes are mentioned as follows:

\section{RESIDENTIAL ENERGY CONSUMPTION CONTROLLING TECHNIQUES}

The generators are sources of electricity which are relying on RES's nuclear fission, oil, and coal (Caron \& Kesidis 2010). Wherever the services between users and companies are managed by service providers. After which users can utilize, generate, store, and sell electricity on local bases, which will help in the energy balancing of the smart grid (Mbungu et al. 2019). The PAR can be controlled by realizing its dependence which is highly affected on time and climate of the day (Lee et al. 2012). However, smart grids are based on the following main parts as seen from Figure 2.

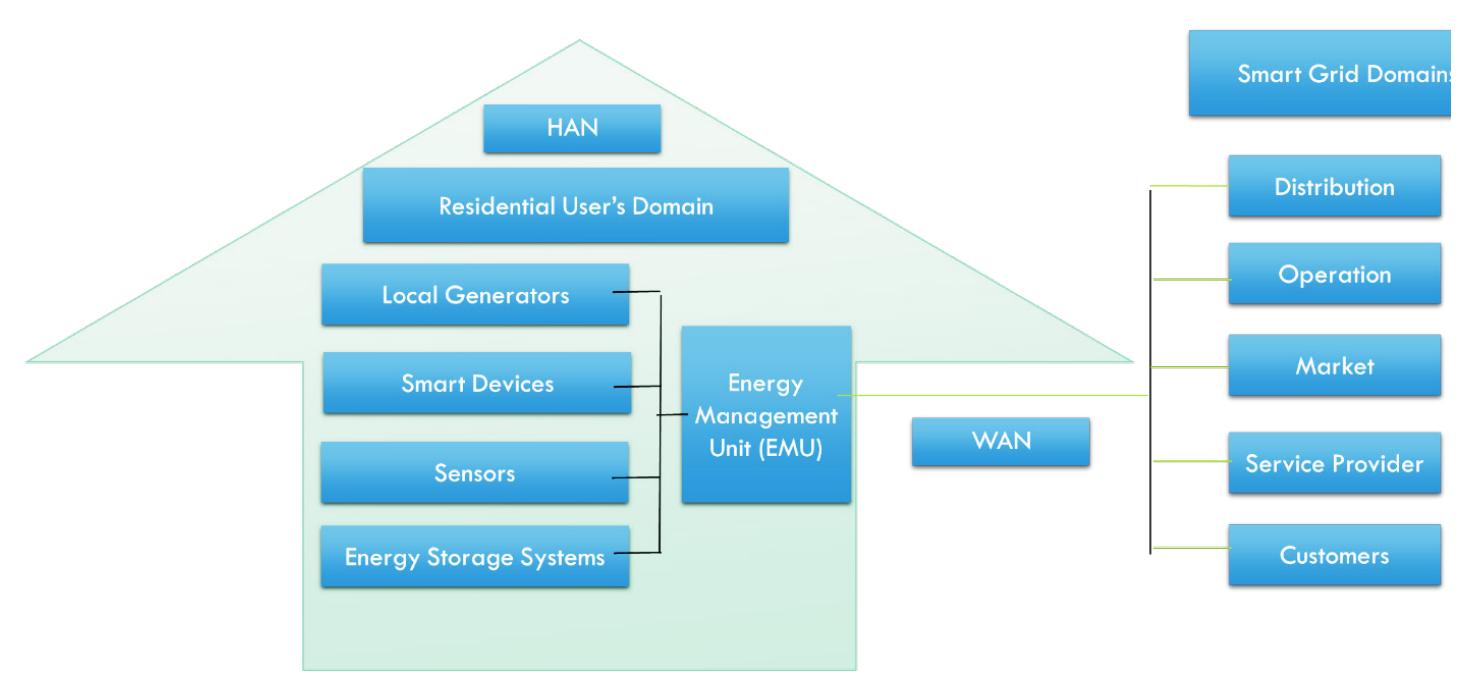

FIGURE 2. The architecture of demand-side management frameworks

(Barbato \& Capone 2014)

HAN: Home area network; Micro generators: To produce energy at a small level; Smart devices: automated and remote devices; Sensors: which can sense and forward data; Energy storage systems: which can store energy, it's useful as this energy will be used in peak hours to minimize bills; The energy management unit (EMU): Which manage the energy by giving schedules, minimize bill by looking at both grid prices and user's needs. WAN: Wide area network. 


\section{HOME APPLIANCES COORDINATION SCHEME FOR ENERGY MANAGEMENT}

The home appliances coordination scheme for energy management (HACS4EM) scheme is made to manage bills of the residential sector the three main bases of this scheme are Smart meter, smart appliances, and wireless sensor home area network (WSHAN) (Wang \& Tu 2020). Smart appliances mainly have energy management units (EMU) which will be responsible for ON/OFF any device in a given time limit of users irrespective of peak hours but HACS4EM will check price and inform users.

\section{EMU}

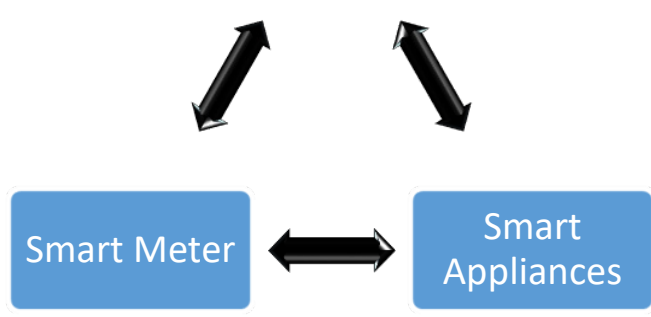

FIGURE 3. Interaction among Major Entities of HACS4EM

(Mahmood et al. 2014)

When any device is turned ON, the device asks from EMU, then EMU checks the available stored energy and gets information from smart meter about the recent prices. Then it makes a schedule for the appliance by using the HACS4EM algorithm (Geraldo et al. 2019). However, if stored energy is sufficient then it operates on by utilizing it otherwise EMU sends schedule details to the user, after that the user will decide to either turn ON the device immediately or delay it for off-peak hours. EMU also have to turn OFF stand by devices in peak hours, because they also consume part of electricity while in stand by position.
In HACS4EM (Mahmood et al. 2014), the shifting of load techniques also controls the delay (Figure 3). Because the delay is inversely proportional to comfort. Therefore, in case of delay time increase from maximum settled delay, HACS4EM will automatically the device regardless of the peak or off-peak hour.

However, the wireless sensor network (WSN) used in HACS4EM is Zigbee which is an IEEE 802.15.4 technique covering the $10-75 \mathrm{~m}$ area. WSN is preferred since it is less expensive and has a long battery life of sensors (Jawad et al. 2019). In Zigbee, both star and mesh topology are utilized using the cluster tree technique as shown in Figure 4 for wireless sensor home area network (WSHAN).

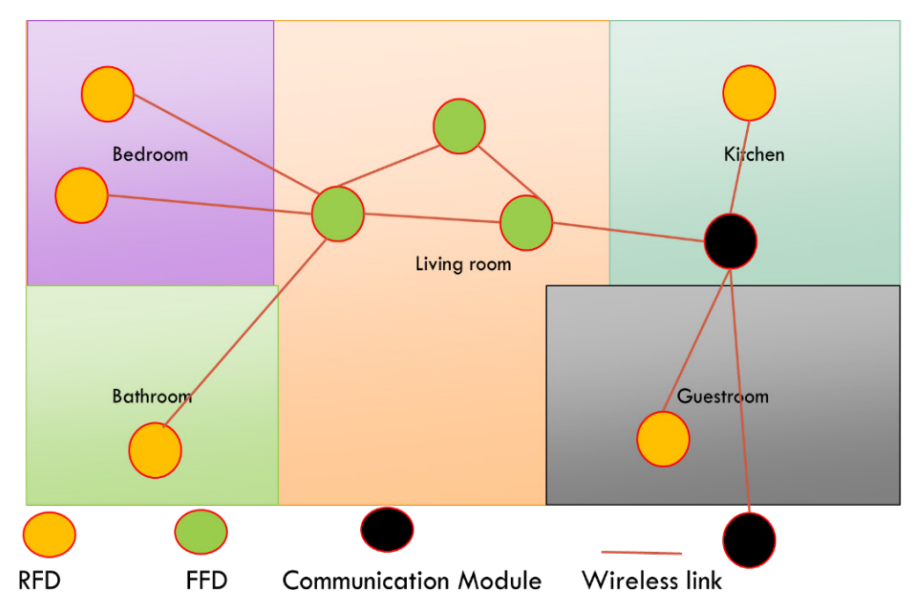

FIGURE 4. WSHAN Topology in HACS4EM (Mahmood et al. 2014) 
It has full and reduced functional devices i.e., FFD, RFDs. The FFD is in a mesh topology and can communicate with other devices while RFD can only sense and forward data they are end devices. Different rooms are playing the role of nodes for RFD and the smart meter is acting as coordinator for FFD of personal area network PAN which is under EMU. In addition to that, the carrier sense multiple access with collision avoidance (CSMA/ CA) technique is used to avoid collision of transferring packets, where each packet can only communicate inactive time of the device.

\section{DSM THREE-LAYERED AUTONOMOUS STRUCTURED MODEL}

DSM three-layered autonomous structured model is another smart scheme in the literature (Lee et al. 2012), where an autonomous model for DSM is used to decrease peak load demands by using load balances (LB), admission controls (AC) and demand response manager (DRM) and loads are also divided as: Baseline load (most important): ON immediately e.g. light; Burst Load: ON in given time e.g. dishwasher; Regular load: ON every time e.g. refrigerator.

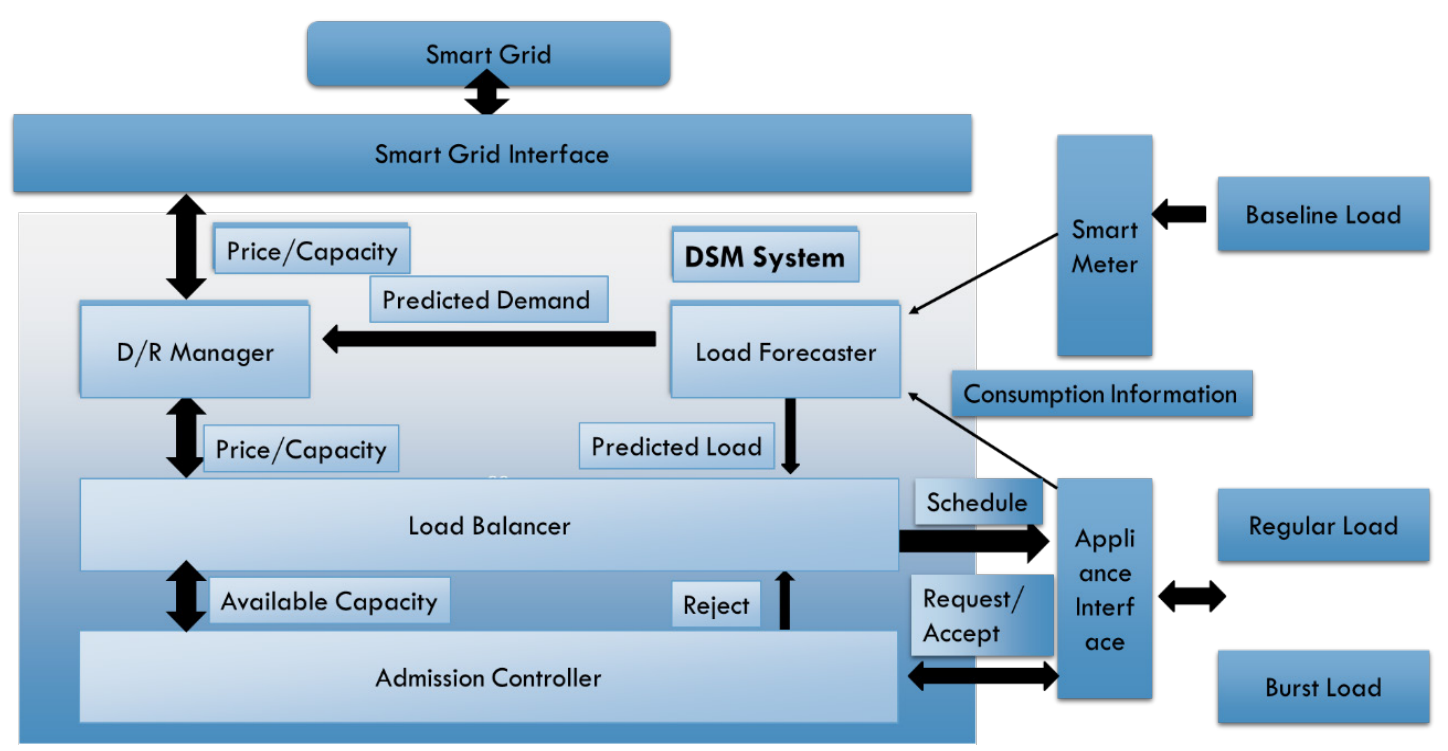

FIGURE 5. Three-layered architecture for load management on demand-side (Lee et al. 2012)

The whole procedure is explained through Figure 5 , where AC makes schedules for every load, based on priority like how much stored energy is available and how much is required for any device. Although the LB schedules for AC's rejected requests based on real-time prices and possible delays. In these ways, the cost is also controlled.

\section{LOAD CONTROL BY BACK-TRACKING TECHNIQUE}

Load control by the back-tracking technique is another smart scheme that operates in real-time (Abdolrasol et al. 2018; Ahmed et al. 2017). The load control by the back-tracking technique defines in advance the start time, end time, and the deadline for maximum delay of the device (Guha et al. 2020). These parameters are sending information regarding non-preemptive or preemptive time, task activation time, deadline, and operation length in advance. Subsequently, because of the dead time of each device different schedules are offered by the scheduler at every hour and then smart appliances while considering the consumer prioritize to select the most feasible solution which helps in reducing peak load.

\section{DSM BASED ON GAMING THEORY}

The DSM based on the gaming theory scheme works on the base of energy consumption scheduler which is the main component here (Rayati et al. 2020). The scheduler considers the shift able (PHEV's, dryer) and non-shift able (light, TV) loads. Accordingly, it turns ON and OFF the loads by the make schedules. The resulting decreased bills for residents by simulations show that PAR is $17 \%$ better where $18 \%$ cost is reduced (Mohsenian-Rad et al. 2010). 
In another project, an autonomous demand-side management gaming theory algorithm is explained with modification where the customer's privacy was also considered. The MATLAB simulation model is explained where the desired demand curve of the consumers through MATLAB simulations and fascinating results are achieved with a secured DSM system (Lee 2020).

\section{PRICE PREDICTING MODEL}

Another technique is the price prediction model. It works in such a way that if some appliance consumer wants to turn $\mathrm{ON}$. Then, the smart meter will check the real-time price (Ghadimi et al. 2018; Shi et al. 2018). If it is more than previous, then the scheduler will predict a future increase in price in upcoming hours. However, if it is less then it will predict decrease and make a schedule accordingly (Pallonetto et al. 2019).

\section{DSM BASED ON VICKREY-CLARKE-GROVES}

Vickrey-Clarke-Groves (VCG) is the DSM scheme that works on run time bases, all users send their energy demand to utility with information about a list of must-run nodes and controllable loads. Then, VCG provides an optimum scheme for customers in real-time and forward (Samadi et al. 2012) and some techniques are also depending on the history of the load fluctuations (Bao et al. 2018). Accordingly, the smart devices operate and get the best schedule price which helps in the reduction of load and cost is up to 38 and $37 \%$ (Samadi et al. 2012).

This brief article summarized the study of different techniques concerning their methods, load and cost minimization, scheduling, pricing, and coverage range. Hence, the customers can decide the scheme according to their requirements or can combine two or more to achieve different kinds of benefits as presented in Table 1 .

TABLE 1. Comparison of different Energy consumption controlling schemes

\begin{tabular}{lcccc}
\hline \multicolumn{1}{c}{ Optimization method } & Scheduling & Coverage & Privacy & References \\
\hline $\begin{array}{l}\text { Load control Scheduling } \\
\text { model }\end{array}$ & Real-time & Local & High & $\begin{array}{c}\text { 2019) } \\
\text { (Costanzo et al. 2012; Mbungu et al. }\end{array}$ \\
$\begin{array}{l}\text { Back-tracking } \\
\text { based scheduling }\end{array}$ & Real-time & Local & Low & $\begin{array}{c}\text { (Guha et al. 2020; Abdolrasol et al. } \\
\text { 2018) Ahmed et al. 2017) }\end{array}$ \\
$\begin{array}{l}\text { Game-theoretic } \\
\text { pricing \& } \\
\text { scheduling }\end{array}$ & Run time & Neighbor-hood & High & (Rayati et al. 2020; Lee 2020) \\
$\begin{array}{l}\text { Scheduling and } \\
\text { Optimization }\end{array}$ & Run time & Neighbor-hood & High & (Bao et al. 2018; Samadi et al. 2012) \\
\hline
\end{tabular}

\section{CONCLUSION}

The main aim of the smart grid is not only to decrease bills but also to utilize the electric grids efficiently. This will enhance the productivity by shifting loads, using storage devices, and microgrids. Covering customer's demands by using energy-efficient techniques of scheduling with keeping an eye on both DR and DSM of residents.

This short survey reports that the best-proposed scheme can be achieved by combining different techniques by comparing their security, cost efficiency, delay, and cooperative methods for real-time users.
The advanced cooperative tools in case of stochastic processes and simulative software can also aid in scheme selection. However, the customer should not only rely on mathematical results. There is a need for micro level grids implementations to achieve some realistic data. This realtime data will aid consumers to utilize these algorithms efficiently by reducing further network losses.

\section{ACKNOWLEDGEMENTS}

The authors are thankful to the LRGS/1/2019/UKMUKM/6/1 grant of Universiti Kebangsaan Malaysia for supporting this study. 


\section{REFERENCES}

Abdolrasol, M.G., Hannan, M.A., Mohamed, A., Amiruldin, U.A.U., Abidin, I.B.Z. \& Uddin, M.N. 2018. An optimal scheduling controller for virtual power plant and microgrid integration using the binary backtracking search algorithm. IEEE Transactions on Industry Applications 54(3): 2834-2844.

Ahmed, M.S., Mohamed, A., Khatib, T., Shareef, H., Homod, R.Z. \& Abd Ali, J. 2017. Real time optimal schedule controller for home energy management system using new binary backtracking search algorithm. Energy and Buildings 138(2017): 215-227.

Akestoridis, D.G., Harishankar, M., Weber, M. \& Tague, P. 2020. Zigator: Analyzing the security of zigbee-enabled smart homes. In Proceedings of the 13th ACM Conference on Security and Privacy in Wireless and Mobile Networks ACM. pp. 77-88.

Alsharif, M.H., Nordin, R. \& Ismail, M. 2016. Green wireless network optimisation strategies within smart grid environments for Long Term Evolution (LTE) cellular networks in Malaysia. Renewable Energy 85: 157-170.

Bao, Z., Qiu, W., Wu, L., Zhai, F., Xu, W., Li, B. \& Li, Z. 2018. Optimal multi-timescale demand side scheduling considering dynamic scenarios of electricity demand. IEEE Transactions on Smart Grid 10(3): 2428-2439.

Barbato, A. \& Capone, A. 2014. Optimization models and methods for demand-side management of residential users: A survey. Energies 7(9): 5787-5824.

Caron, S. \& Kesidis, G. 2010. Incentive-based energy consumption scheduling algorithms for the smart grid. In 2010 First IEEE International Conference on Smart Grid Communications. pp. 391-396.

Costanzo, G.T., Zhu, G., Anjos, M.F. \& Savard, G. 2012. A system architecture for autonomous demand side load management in smart buildings. IEEE Transactions on Smart Grid 3(4): 2157-2165.

Costanzo, G.T., Kheir, J. \& Zhu, G. 2011. Peak-load shaving in smart homes via online scheduling. 2011 IEEE International Symposium on Industrial Electronics. pp. 1347-1352.

Fatima, N., Karimov, K.S., Qasuria, T.A. \& Ibrahim, M.A. 2020. A novel and stable way for energy harvesting from Bi2Te3Se alloy based semitransparent photo-thermoelectric module. Journal of Alloys and Compounds 849: 156702.

Filho, G.P.R., Villas, L.A., Gonçalves, V.P., Pessin, G., Loureiro, A.A. \& Ueyama, J. 2019. Energy-efficient smart home systems: Infrastructure and decision-making process. Internet of Things 5: 153-167.

Ghadimi, N., Akbarimajd, A., Shayeghi, H. \& Abedinia, O. 2018. A new prediction model based on multi-block forecast engine in smart grid. Journal of Ambient Intelligence and Humanized Computing 9(6): 1873-1888.

Guha, D., Roy, P. \& Banerjee, S. 2020. Quasi-oppositional backtracking search algorithm to solve load frequency control problem of interconnected power system. Iranian Journal of Science and Technology Transactions of Electrical Engineering 44(2): 781-804.

Hajjawi, A. \& Ismail, M. 2015. A scheduling algorithm based self-learning technique for smart grid communications over 4G networks. Journal of Communications 10(11): 876-881.
Hannan, M.A., Tan, S.Y., Al-Shetwi, A.Q., Jern, K.P. \& Begum, R.A. 2020. Optimized controller for renewable energy sources integration into microgrid: Functions, constraints and suggestions. Journal of Cleaner Production 256(2020): 120419.

Ibrahim, A.M., Attia, M.A. \& Abdelaziz, A.Y. 2020. A DSM approach for distribution systems with high wind power penetration. Electric Power Components and Systems 2012: $1-14$.

Jawad, H.M., Jawad, A.M., Nordin, R., Gharghan, S.K., Abdullah, N.F., Ismail, M. \& Abu-AlShaeer, M.J. 2019. Accurate empirical path-loss model based on particle swarm optimization for wireless sensor networks in smart agriculture. IEEE Sensors Journal 20(1): 552-561.

Karimov, K.S., Fatima, N., Qasuria, T.A., Siddiqui, K.J., Bashir, M.M., Alharbi, H.F., Alharth, N.H., Al-Harthi, Y.S., Amin, N. \& Akhtaruzzaman, M. 2020. Innovative semitransparent photo-thermoelectric cells based on bismuth antimony telluride alloy. Journal of Alloys and Compounds 816(2020): 152593.

Lee, J., Kim, H.J., Park, G.L. \& Kang, M. 2012. Energy consumption scheduler for demand response systems in the smart grid. Journal of Information Science \& Engineering 28(5): 955-969.

Lee, Z.Y. 2020. Game Theory based Autonomous DSM Algorithm Design. EEE Student Reports (FYP/IA/PA/PI) Nanyang Technological University (Unpublished).

Mahmood, A., Khan, I., Razzaq, S., Najam, Z., Khan, N.A., Rehman, M.A. \& Javaid, N. 2014. Home appliances coordination scheme for energy management (HACS4EM) using wireless sensor networks in smart grids. Procedia Computer Science 32(2014): 469-476.

Mbungu, N.T., Bansal, R.C. \& Naidoo, R.M. 2019. Smart energy coordination of autonomous residential home. IET Smart Grid 2(3): 336-346.

Mohsenian-Rad, A.H., Wong, V.W., Jatskevich, J. \& Schober, R. 2010. Optimal and autonomous incentive-based energy consumption scheduling algorithm for smart grid. Innovative Smart Grid Technologies (ISGT) 2010: 1-6.

Pallonetto, F., De Rosa, M., Milano, F. \& Finn, D.P. 2019. Demand response algorithms for smart-grid ready residential buildings using machine learning models. Applied Energy 239: 1265-1282.

Ramos, J.S., Moreno, M.P., Rodríguez, L.R., Delgado, M.G. \& Domínguez, S.Á. 2019. Potential for exploiting the synergies between buildings through DSM approaches. Case study: La Graciosa Island. Energy Conversion and Management 194: 199-216.

Rayati, M., Bozorg, M., Ranjbar, A.M. \& Cherkaoui, R. 2020. Balancing management of strategic aggregators using noncooperative game theory. Electric Power Systems Research 184(2020): 106297.

Ridzuan, N.H.A.M., Marwan, N.F., Khalid, N., Ali, M.H. \& Tseng, M.L. 2020. Effects of agriculture, renewable energy, and economic growth on carbon dioxide emissions: Evidence of the environmental Kuznets curve. Resources, Conservation and Recycling 160(2020): 104879.

Ruiz, N., Cobelo, I. \& Oyarzabal, J. 2009. A direct load control model for virtual power plant management. IEEE Transactions on Power Systems 24(2): 959-966. 
Samadi, P., Mohsenian-Rad, H., Schober, R. \& Wong, V.W. 2012. Advanced demand side management for the future smart grid using mechanism design. IEEE Transactions on Smart Grid 3(3): 1170-1180.

Shi, Y., Tuan, H.D., Savkin, A.V., Duong, T.Q. \& Poor, H.V. 2018. Model predictive control for smart grids with multiple electric-vehicle charging stations. IEEE Transactions on Smart Grid 10(2): 2127-2136.

Wang, P. \& Tu, G. 2020. Localization algorithm of wireless sensor network based on matrix reconstruction. Computer Communications 154: 216-222.

Wilkes, J., Moccia, J. \& Drangan, M. 2012. Wind in power: 2011 European Wind Statistics, European Wind Energy Association Technical Report EWEA. pp. 1-11.

Wu, Q., Wang, P. \& Goel, L. 2010. Direct load control (DLC) considering nodal interrupted energy assessment rate (NIEAR) in restructured power systems. IEEE Transactions on Power Systems 25(3): 1449-1456.

Xia, K., Ni, J., Ye, Y., Xu, P. \& Wang, Y. 2020. A realtime monitoring system based on ZigBee and $4 \mathrm{G}$ communications for photovoltaic generation. CSEE Journal of Power and Energy Systems 6(1): 52-63.
Zhao, X., Guerrero, J.M., Savaghebi, M., Vasquez, J.C., Wu, X. \& Sun, K. 2016. Low-voltage ride-through operation of power converters in grid-interactive microgrids by using negative-sequence droop control. IEEE Transactions on Power Electronics 32(4): 3128-3142.

Noshin Fatima* \& Mohd. Adib Ibrahim

Solar Energy Research Institute

Universiti Kebangsaan Malaysia

43600 UKM Bangi, Selangor Darul Ehsan

Malaysia

Tahseen Amin Qasuria

Ghulam Ishaq Khan Institute of Engineering Sciences and Technology

Topi-23640, KPK

Pakistan

*Corresponding author; email: noshinfatima1990@gmail.com

Received: 11 August 2020

Accepted: 19 August 2020 